\title{
Physicochemical Properties of Cheddar Cheese made from Citrus reticulata Blanco Crude Flowers Extract
}

\author{
Usman Mir Khan ${ }^{1, a, *}$, Ishtiaque Ahmad ${ }^{1, b}$, Saima Inayat ${ }^{1, c}$, Hafiz Muhammed Arslan Amin ${ }^{1, d}$, \\ Zeliha Selamoglu',e \\ ${ }^{1}$ Department of Dairy Technology, Faculty of Animal Production and Technology, University of Veterinary and Animal Sciences, Lahore, \\ 54000, Pakistan \\ ${ }^{2}$ Department of Medical Biology, Faculty of Medicine, Niğde Ömer Halisdemir University Campus, 51240, Niğde, Turkey
} *Corresponding author

\section{A R T I C LE IN F O}

Research Article

Received : 19/12/2018

Accepted : 24/04/2019

Keywords: Cheddar Cheese Citrus reticulata Blanco Buffalo Milk

Milk Coagulant Cheddar cheese

\section{A B S T R A C T}

Citrus reticulata Blanco crude flowers extracts (CFE) at four different concentrations (1, 2, 3 and $4 \%, \mathrm{v} / \mathrm{v})$ were used as natural milk coagulant instead of rennet to apply for Cheddar cheese making from buffalo milk. The physicochemical properties of Cheddar cheeses were compared with cheese made with $0.002 \%(\mathrm{v} / \mathrm{v})$ rennet (control cheese). Physicochemical properties of Cheddar cheese showed that cheese made with $1 \%$ and $2 \%$ of CFE had a crumbly and slightly softer texture/appearance. While cheeses containing 3 and $4 \%$ crude flowers extracts had semi-hard texture/appearance of curd similar to rennet added cheese. Protein analysis shows that crude flowers extracts made cheese had significantly higher protein content than control. The Cheddar cheese with $3 \%$ and $4 \%$ CFE were preferred by panelists instead of $1 \%$ and $2 \%$ CFE for their taste, texture/appearance and overall acceptability. Conclusively, crude flowers extracts coagulated Cheddar cheese fulfills the compositional requirement with acceptable organoleptic characteristics and at the same time provides nutritional health benefits.

\section{Introduction}

Cheese as one of the major fermented dairy product is an excellent source of high quality protein and milk fat needed for human health. It is a rich source of fat soluble vitamins and also an important source of minerals (calcium and phosphorous) and concentrated source of energy. Cheese is valued for its long life and differs from country to country in colors, flavor, and texture (Fox et al., 2000; Donnelly et al. 2010).

Cheese industry in Pakistan is in growing stage and needs new innovation and technologies for its development and sustainability. The basic demand of food industry is to have consistent and reproducible characteristics for quality and processing of food products in food industry (Murtaza et al., 2008).

Traditionally, rennet is abomasum source of slaughtered young calves. In Pakistan, there is now decrease in slaughtering of young calves according to Pakistan Food Authority rules, as nowadays calves are grown for their meat production and which ultimately leads to less availability and shortage of natural rennet. So to fill this gap alternatives of rennet are used in cheese production. In countries with majority of vegetarian population, there is less availability of rennet from animals for cheese production. Therefore, alternatives in milk coagulation process will be economical for cheese production in developed countries (Fox et al., 2000; Andren, 2011).

Several alternative proteases obtained from different vegetable and fruit sources (e.g., kiwi, melon and papaya), roots (e.g., ginger), latex (e.g., papaya fruit and sodom apple) and flowers (e.g., Citrus aurantium sp., Cynara cardunculus and Centaurea calcitrapa) have been recommended as milk-clotting agents in cheese processing (Adetunji and Salawu, 2008; Domsalla and Melzig, 2008; Fernandez-Salguero et al. 2002). Additionally, these plant extracts have unique functional properties in flavor and texture, and will lead to innovative applications in new product development (Harboe et al., 2010). 
Pakistan is in the sixth position in production of kinnow and oranges in the world with 1.9 million tons production yearly (Sharif et al., 2014). Proteins and enzymes present in kinnow are nutritional compounds which are also beneficial for human health. Kinnow (Citrus reticulata Blanco) known as bitter orange grows in most of subtropical climate and most of its fruits and flowers are discarded. Therefore, it is important to make more proficient use of agricultural and industrial products like seeds, leaves, flowers and other organic materials to have benefits in the economical, ecological and technological points of view (Silvestre et al., 2012).

Kinnow has proteolytic enzyme which can be obtained from generative organs of flowering plants. Plant tissues present in kinnow contain a wide range of proteins varying in functional properties. Protein content of prepared crude flowers extract (CFE) was in the range of 20 to $35 \mathrm{mg} / \mathrm{mL}$ and soluble protein in the citrus flower increased up to $85 \%$ of the total protein content at final floral development (Radlowski, 2005).

Rennet production is time consuming and costly. CFE has a typical aroma and flavor and it contains citrase with the activity to coagulate the milk (Mazorra-Manzano et al., 2013). Furthermore, Pakistan is a Muslim country and there is a controversy in using rennet for the production of cheese. Therefore, the objectives of this study is to provide economical, easily available and new milk coagulant, Citrus reticulata Blanco CFE to use in Cheddar cheese production technology as a source of milk-clotting enzyme in cheese production technology. The physicochemical characteristics and sensory evaluation of Cheddar cheese made with CFE were compared to rennet coagulated Cheddar cheese.

\section{Materials and Methods}

\section{Materials}

Flowers of Citrus reticulata Blanco were collected during blossom periods (mid of March to end of April and mid of September to end of October, 2015) from Sargodha District nurseries, Faisalabad Road, Sargodha. Flowers were collected and stored in freezer in food grade bags at $20^{\circ} \mathrm{C}$ to keep them fresh. Five liters of buffalo milk were used for each treatment of Cheddar cheese production. Buffalo milk was procured from the Dairy Animals Training and Research Center, UVAS, Ravi Campus, Pattoki.

\section{Preparation of Citrus reticulata Blanco CFE}

CFE was prepared by blending citrus flowers with 5 parts of cold buffer $(20 \mathrm{mmol} / \mathrm{L}$ of Tris- $\mathrm{HCl})$ having $\mathrm{pH}$ 7.20 in an electrical blender for 3 intermittent periods of 15 seconds. The blended sample was filtered by using a cheese cloth and then centrifuged at $850 \mathrm{~g}, 10^{\circ} \mathrm{C}$ for 30 minutes (Hemle Bench Top Centrifuge, Wehingen, Germany). Centrifugation of extract with Tris-HCL buffer leads to the activation of citrase. Then separate the aqueous phase of CFE from settled pallet by gradually pouring in the plastic test tubes. Then aqueous extract was kept in a refrigerator at $4{ }^{\circ} \mathrm{C}$ until analysis (Mazorra-Manzano et al., 2013).

\section{Manufacturing of Cheddar Cheese}

Prior to the cheese making, five liters of buffalo milk for each treatment were pasteurized at $65^{\circ} \mathrm{C}$ for 30 minutes and then cooled at $33^{\circ} \mathrm{C}$. Then, the milk was inoculated with $2 \%$ of starter cultures (v/v) (Lactococcus lactis subsp. lactis and Lactococcus lactis subsp. cremoris, availed from Danisco Dairy Cultures, Paris, France) (Walstra et al., 2006). A control sample $\left(\mathrm{T}_{0}\right)$ was coagulated with $0.002 \%$ rennet (Rennet strength is 20 International Milk-Clotting Units, IMCU $/ \mathrm{mL}$ ) at $33^{\circ} \mathrm{C}$ for 45 minutes and it was obtained from Danisco Dairy Cultures (Paris, France) while the other four samples were coagulated using Citrus reticulata Blanco $\mathrm{CFE}$ at different concentrations of $1 \%$ $\left(\mathrm{T}_{1}\right), 2 \%\left(\mathrm{~T}_{2}\right), 3 \%\left(\mathrm{~T}_{3}\right)$ and $4 \%\left(\mathrm{~T}_{4}\right)(\mathrm{v} / \mathrm{v})$ at $33^{\circ} \mathrm{C}$ for 45 minutes. After the curd was firm enough, it was then cut and stirred to drain whey. Then, curd was cooked and milled at $33^{\circ} \mathrm{C}$ for 15 minutes. After that blocks were turned up and down to separate more whey from the curd of cheese (Andren, 2011). This block of cheese was kept warm and then cheddaring of block led to acid development at final $\mathrm{pH}$ of 5.52 to 5.54. Salting was done at the rate of $2.5 \%(\mathrm{w} / \mathrm{w})$ and whey was removed by pressing the cheese blocks with cheese presser. Storage and ripening of cheese was done at $10^{\circ} \mathrm{C}$ for 63 days (Walstra et al., 2006). Waxing of Cheddar cheese was done by pure paraffin wax (obtained from BW Chemicals, Lahore, Pakistan) to preserve it from molds and other contaminants (Figure 1).

\section{Physicochemical Analysis}

Moisture, fat, protein, and salt contents and $\mathrm{pH}$ values of Cheddar cheeses were done according to the methods prescribed by AOAC (2000) at storage (during 0 and 63 days).

\section{Sensory Evaluation}

Samples of Cheddar cheeses were coded with three digit random numbers and randomly served to semi-trained panels for sensory evaluation at 63 days of storage. The sensorial attributes were carried out on basis of texture/appearance, taste, color, odor and overall acceptability on a 9-point hedonic scale $(9=$ dislike very much; 1 = like very much) (Meilgaard et al., 2007). The panelists (comprised of 50 semi-trained panelists) were provided with respective cheese samples at room temperature. Panelists were given deionized water to cleanse their palates after evaluating each sample.

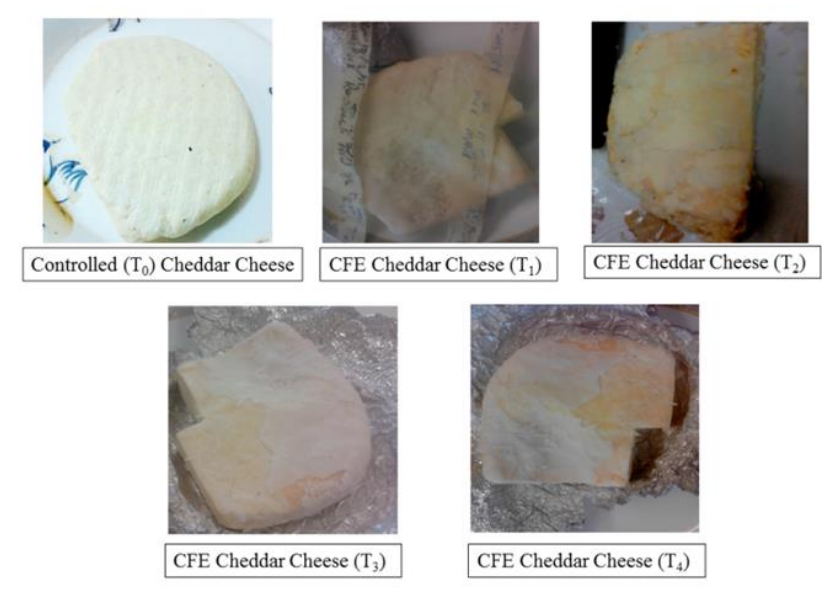

Figure 1 Control $\left(\mathrm{T}_{0}\right)$ as rennet coagulated and treatments $\left(\mathrm{T}_{1}, \mathrm{~T}_{2}, \mathrm{~T}_{3}\right.$ and $\left.\mathrm{T}_{4}\right)$ as crude flowers extracts (CFE) coagulated cheeses after 63 days of storage period 


\section{Statistical Design}

All data were analyzed using two-way Analysis of Variance (ANOVA) technique under Completely Randomized Design (Steel et al., 1997). Duncan's Multiple Range Test at $\mathrm{P}<0.05$ was used for comparison of significant differences (SAS 9.1 Statistical Software).

\section{Results and Discussion}

\section{Physicochemical Analysis}

The Cheddar cheeses prepared using $1 \%$ and $2 \%$ of CFE showed higher fat contents from 0 to 63 days of ripening while cheese prepared with $3 \%$ and $4 \%$ of $\mathrm{CFE}$ have lower fat contents than control one (Table 1). Fat contents lead to a fatty appearance, specific aroma and flavor development in Cheddar cheeses (Singh et al., 2003). High protein contents were observed in Cheddar cheeses with $4 \%$ CFE after 63 days of storage because CFE contains protein which ranges from 20 to $35 \mathrm{mg} / \mathrm{mL}$. Rennet coagulated Cheddar cheese showed protein content of $26.53 \%$ at 0 days of storage which decreased to $26.22 \%$ after 63 days of storage. This protein content is similar to standard protein contents for Cheddar cheese which range from $24 \%$ to $27 \%$ protein content (Chang, 2010). Citrus reticulata Blanco CFE provides enhancement of protein level in Cheddar cheese. Proteolysis of proteins increases at storage temperature of $10^{\circ} \mathrm{C}$ which leads to development of flavor and aroma as described by Wang et al. (2011). There was a decreasing trend in moisture content after 63 days of storage at $10^{\circ} \mathrm{C}$ because of the environment and storage variations. Cheddar cheeses made from $1 \%$ and $2 \%$ of crude flower extract showed slightly higher moisture contents while Cheddar cheeses prepared from 3\% and $4 \%$ of CFE showed $33 \%$ moisture content which is almost similar to the rennet coagulated Cheddar cheese with $32 \%$ moisture content as reported by Zheng et al. (2011). The $\mathrm{pH}$ of cheese samples ranged from 5.54 to 5.52 throughout the storage (Table 1). CFE Cheddar cheese prepared with 1,2 and $3 \%$ showed $\mathrm{pH}$ of 5.53 at 0 days and decreased to 5.52 which is standard $\mathrm{pH}$ of the Cheddar cheese as described by Pastorino et al. (2003). The decrease in $\mathrm{pH}$ of Cheddar cheese was due to breakdown of lactose into lactic acid during ripening stage of $10^{\circ} \mathrm{C}$ (Onga et al., 2007). Cheeses with a normal $(1.7 \%)$ and high $(2.3 \%)$ salt content suppress bitterness and un-natural flavor of cheese (Moller et al., 2013). Salt concentration of Cheddar cheeses decreases in ripening stage as salt come out with water after pressing of cheese blocks or during storage at $10^{\circ} \mathrm{C}\left(\mathrm{O}^{\prime}\right.$ Mahony et al., 2005).

\section{Sensory Evaluation}

Results showed that cheeses made with $1 \%$ and $2 \%$ of CFE had a crumbly and slightly softer texture/appearance. Cheeses contained $3 \%$ and $4 \%$ CFE had semi-hard texture/appearance which is similar to rennet added cheese as reported by Prinsloo (2007). Cheddar cheese coagulated with $1 \%$ CFE showed light yellow color while $4 \%$ CFE was yellow in color during all the ripening period due to the higher amount of the CFE. The color observed by using $4 \%$ CFE was quite resembled to standard Cheddar cheese (Young et al., 2004). Control Cheddar cheese prepared with rennet resulted "salty", "fatty" and "slight sour" taste while 3\% CFE resulted with "low sour", "sweet", 'buttery" and "high salty" taste. Cheddar cheese with $1 \%$ and $4 \%$ CFE showed "bitter "and "umami" tastes (Caspia et al. 2006). Sources of bitterness were excessive accumulation of small hydrophobic peptides and a lack of masking compounds (primarily salt) in curd of cheese (Singh et al., 2003). Cheddar cheese with $3 \%$ and $4 \%$ CFE showed higher aroma intensity while $1 \%$ and $2 \%$ CFE showed less intense aroma as compared to standard Cheddar cheese which have typical aroma. The better sensory score was taken by $3 \%$ and $4 \%$ of CFE coagulated Cheddar cheeses as compared to $1 \%$ and $2 \% \mathrm{CFE}$ at 63 days of storage. Cheddar cheese with higher CFE developed bitter flavor. The most liked Cheddar cheese sample was rennet coagulated Cheddar which showed smooth/creamy, hard, compact, smooth surface, rubbery, fatty, smeary, sticky and shiny appearance. Texture of Cheddar cheese changes as ripening accelerates after 12 months' period of storage. Significant differences observed in firmness and crumbliness after analyzing which showed that there are texture/appearance differences in CFE coagulated Cheddar cheeses with comparison to control one (Table 2).

Table 1 Effect of Different Treatments of Crude Flowers Extracts (CFE) on Physico-Chemical Properties of Control (Rennet Coagulated) and CFE Coagulated Treatments

\begin{tabular}{l|llllll}
\hline \multirow{2}{*}{ Treatments } & Storage & \multicolumn{5}{|c}{ Physicochemical Analysis of CFE Cheddar cheese } \\
\cline { 2 - 7 } & Days & Fat (\%) & Protein $(\%)$ & Moisture (\%) & pH & Salt $(\%)$ \\
\hline \multirow{2}{*}{ T0 } & Day 0 & $33.37 \pm 0.17^{\mathrm{a}}$ & $26.53 \pm 0.01^{\mathrm{ab}}$ & $37.09 \pm 0.020^{\mathrm{d}}$ & $5.54 \pm 0.000^{\mathrm{d}}$ & $2.50 \pm 0.01^{\mathrm{a}}$ \\
& Day 63 & $32.28 \pm 0.34^{\mathrm{a}}$ & $26.22 \pm 0.003^{\mathrm{a}}$ & $35.94 \pm 0.010^{\mathrm{c}}$ & $5.52 \pm 0.003^{\mathrm{a}}$ & $2.47 \pm 0.01^{\mathrm{b}}$ \\
\hline \multirow{2}{*}{$\mathrm{T} 1$} & Day 0 & $32.95 \pm 0.17^{\mathrm{a}}$ & $27.34 \pm 0.10^{\mathrm{b}}$ & $36.78 \pm 0.030^{\mathrm{c}}$ & $5.53 \pm 0.003^{\mathrm{bc}}$ & $2.50 \pm 0.01^{\mathrm{a}}$ \\
& Day 63 & $32.57 \pm 0.44^{\mathrm{ab}}$ & $29.05 \pm 0.03^{\mathrm{d}}$ & $34.31 \pm 0.010^{\mathrm{b}}$ & $5.52 \pm 0.003^{\mathrm{a}}$ & $2.41 \pm 0.01^{\mathrm{b}}$ \\
\hline \multirow{2}{*}{$\mathrm{T} 2$} & Day 0 & $33.90 \pm 0.33^{\mathrm{b}}$ & $28.66 \pm 0.08^{\mathrm{a}}$ & $35.30 \pm 0.020^{\mathrm{a}}$ & $5.53 \pm 0.003^{\mathrm{cd}}$ & $2.5 \pm 0.01^{\mathrm{a}}$ \\
& Day 63 & $32.04 \pm 0.17^{\mathrm{bc}}$ & $30.45 \pm 0.01^{\mathrm{e}}$ & $34.22 \pm 0.006^{\mathrm{a}}$ & $5.52 \pm 0.006^{\mathrm{a}}$ & $2.42 \pm 0.01^{\mathrm{b}}$ \\
\hline \multirow{2}{*}{$\mathrm{T} 3$} & Day 0 & $33.13 \pm 0.17^{\mathrm{a}}$ & $27.47 \pm 0.02^{\mathrm{ab}}$ & $36.28 \pm 0.010^{\mathrm{c}}$ & $5.53 \pm 0.003^{\mathrm{b}}$ & $2.49 \pm 0.02^{\mathrm{b}}$ \\
& Day 63 & $31.25 \pm 0.17^{\mathrm{c}}$ & $30.53 \pm 0.01^{\mathrm{c}}$ & $33.12 \pm 0.004^{\mathrm{d}}$ & $5.52 \pm 0.003^{\mathrm{a}}$ & $2.43 \pm 0.07^{\mathrm{a}}$ \\
\hline \multirow{2}{*}{ T4 } & Day 0 & $34.03 \pm 0.17^{\mathrm{b}}$ & $28.21 \pm 0.24^{\mathrm{b}}$ & $35.62 \pm 0.020^{\mathrm{b}}$ & $5.52 \pm 0.003^{\mathrm{a}}$ & $2.50 \pm 0.01^{\mathrm{c}}$ \\
& Day 63 & $31.20 \pm 0.44^{\mathrm{ab}}$ & $32.38 \pm 0.01^{\mathrm{b}}$ & $32.95 \pm 0.006^{\mathrm{d}}$ & $5.53 \pm 0.003^{\mathrm{a}}$ & $2.42 \pm 0.01^{\mathrm{c}}$ \\
\hline
\end{tabular}

*All values are triplicate means of each treatment, ${ }^{* * D}$ Different lower case alphabets showing significant differences among different treatments $(\mathrm{P}<0.05), \mathrm{T}_{0}=$ Controlled Cheddar cheese with rennet, $\mathrm{T}_{1}=$ Cheddar cheese prepared with $1 \%$ Citrus aurantium $\mathrm{CFE}$, $\mathrm{T}_{2}=$ Cheddar cheese prepared with $2 \%$ Citrus aurantium $\mathrm{CFE}, \mathrm{T}_{3}=$ Cheddar cheese prepared with $3 \%$ Citrus aurantium $\mathrm{CFE}, \mathrm{T}_{4}=$ Cheddar cheese prepared with $4 \%$ Citrus aurantium $\mathrm{CFE}$ 
Table 2 Effect of Crude Flowers Extracts (CFE) on Overall Acceptability of Cheddar cheese

\begin{tabular}{l|cccccc}
\hline \multirow{2}{*}{ Treatments } & \multicolumn{6}{|c}{ Sensory Parameters } \\
\cline { 2 - 7 } & Color & Taste & Aroma & Acidity & $\begin{array}{c}\text { Texture/Appe } \\
\text { arance }\end{array}$ & $\begin{array}{c}\text { Overall } \\
\text { Acceptability }\end{array}$ \\
\hline $\mathrm{T}_{0}$ & $2.00 \pm 0.27^{\mathrm{ab}}$ & $2.50 \pm 0.56^{\mathrm{a}}$ & $2.50 \pm 0.33^{\mathrm{ab}}$ & $2.75 \pm 0.36^{\mathrm{ab}}$ & $2.25 \pm 0.31^{\mathrm{ab}}$ & $2.00 \pm 0.46^{\mathrm{c}}$ \\
$\mathrm{T}_{1}$ & $2.12 \pm 0.29^{\mathrm{ab}}$ & $3.50 \pm 0.50^{\mathrm{a}}$ & $3.00 \pm 0.38^{\mathrm{ab}}$ & $2.88 \pm 0.55^{\mathrm{ab}}$ & $2.88 \pm 0.44^{\mathrm{a}}$ & $4.37 \pm 0.37^{\mathrm{a}}$ \\
$\mathrm{T}_{2}$ & $2.75 \pm 0.25^{\mathrm{a}}$ & $3.25 \pm 0.25^{\mathrm{a}}$ & $3.50 \pm 0.38^{\mathrm{a}}$ & $3.75 \pm 0.25^{\mathrm{a}}$ & $2.50 \pm 0.33^{\mathrm{ab}}$ & $5.12 \pm 0.22^{\mathrm{a}}$ \\
$\mathrm{T}_{3}$ & $1.50 \pm 0.19^{\mathrm{b}}$ & $2.37 \pm 0.26^{\mathrm{a}}$ & $2.00 \pm 0.27^{\mathrm{b}}$ & $2.25 \pm 0.16^{\mathrm{b}}$ & $1.62 \pm 0.26^{\mathrm{b}}$ & $1.75 \pm 0.25^{\mathrm{c}}$ \\
$\mathrm{T}_{4}$ & $1.62 \pm 0.26^{\mathrm{b}}$ & $2.87 \pm 0.29^{\mathrm{a}}$ & $2.50 \pm 0.38^{\mathrm{ab}}$ & $2.25 \pm 0.16^{\mathrm{b}}$ & $2.62 \pm 0.37^{\mathrm{ab}}$ & $3.00 \pm 0.33^{\mathrm{b}}$ \\
\hline
\end{tabular}

*All values are triplicate means of each treatment, **Different lower case alphabets showing significant differences among different treatments $(\mathrm{P}<0.05)$.

Overall acceptability is based on panelists' likeness/dis-likeness, quality, appearance, taste, flavor or color preferences. Overall acceptability decreased by $1 \%$ and 2\% CFE treatments because both showed lower bitterness in taste while 3\% CFE was more bitter and accepted by panelists (Table 2). Cheddar cheese acceptance varies distinctively among consumers and related to consumer preference for distinct flavor profile of Cheddar cheese (Young et al., 2004). Cheddar cheese with $3 \%$ and $4 \%$ CFE were preferred by panelists instead of $1 \%$ and $2 \%$ for their better taste, texture/appearance and overall acceptability but they were less preferred over standard Cheddar cheese (control) due to the presence of bitter and intense aroma compounds of Citrus reticulata Blanco flowers.

Thus, additional research must be carried out to find ways to remove the bitterness in CFE coagulated Cheddar cheese. Amino acids profiling is needed to better understand the taste development and to have pleasant aroma.

\section{Conclusions}

This research project was designed to implement and introduce the use of Citrus reticulata Blanco $\mathrm{CFE}$ as an economical, easily available rennet substitute in Cheddar cheese production. The CFE was evaluated for its first time usage as coagulant in Cheddar cheese production and compared with rennet for its physico-chemical characteristics and sensory evaluation. The Cheddar cheeses made with $1 \%$ and $2 \%$ of CFE had a longer and slightly softer texture/appearance. While, cheeses contained $3 \%$ and $4 \% \mathrm{CFE}$ had semi-hard appearance of curd similar to rennet added cheese which is similar to the standard Cheddar cheese made with rennet. The Cheddar cheese with $3 \%$ and $4 \%$ were preferred by panelists instead of $1 \%$ and $2 \%$ for their better taste, appearance and overall acceptability. In future, this research will provide benefits to the cheese industry by introducing a new economical, nutritional and easily available rennet substitute source of milk coagulation. Pakistan is producing largest amount of Citrus reticulata Blanco, so export of CFE to other countries for usage as an alternate of rennet and to provide economic benefits to Pakistan. Furthermore, this research will open new ways for researchers to find out the characterization of extract and enzyme of CFE. However, efficiency and characterization of citrase is still unknown so only its activity is mentioned.

\section{Acknowledgement}

The authors are grateful to Department of Dairy Technology Postgraduate Laboratory of University of Veterinary and Animal Sciences, Pakistan for providing research facilities and their excellent technical assistance.

\section{References}

Adetunji VO, Salawu OT. 2008. West African soft cheese 'wara' processed with Calotropis procera and Carica papaya: A comparative assessment of nutritional values. African. J. Biotechnol. 7(18): 3360-3362.

Andren A. 2011. Cheese: Rennets and Coagulants. Encyclopedia of Dairy Sciences. $2^{\text {nd }}$ Ed. Springer Publishers, New York. 574-578 pp.

AOAC. 2000. Official Methods of anlaysis. American Association of Analytical Chemists. Inc. $17^{\text {th }}$ Ed. Washington, DC.

Caspia EL, Coggins PC, Schilling MW, Yoon Y, White CH. 2006. The relationship between consumer acceptability and descriptive sensory attributes in Cheddar cheese. J. Sens. Stud. 21: 112-127.

Chang SK. 2010. Protein analysis. In Food analysis. Springer US. 133-146 pp.

Domsalla A, Melzig M. 2008. Occurrence and properties of proteases in plant latices. Planta. Medica. 74(7): 699-711.

Donnelly JE, Sullivan DK, Smith BK, Gibson CA, Mayo M, Lee R, Lynch A, Sallee T, Cook-Weins G, Washburn RA. 2010. The Effects of visible cheese on the selection and consumption of food groups to encourage in middle school students. J. Child. Nutr. Manag. 34(1).

Fox PF, Gunee TP, Cogan TM, McSweeney PLH. 2000. Fundamentals of Cheese Science. Aspen Publishers Inc. USA. 1-7: 504-512 pp.

Fernandez-Salguero J, Tejada L, Gomez R. 2002. Use of powdered vegetable coagulant in the manufacture of ewe's milk cheeses. J. Sci. Food Agric. 82(4): 464.

Harboe M, Broe ML, Qvist KB. 2010. The Production, Action and Application of Rennet and Coagulants, Technology of Cheese making, Blackwell Publishing Ltd, pp. 1-45.

Mazorra-Manzano MA, Moreno-Hernandez JM, Ramirez-Suarez JC, Torres-Llanez MdJ, Gonzalez-Cordova AF, VallejoCordoba B. 2013. Sour orange Citrus aurantium L. flowers: A new vegetable source of milk-clotting proteases. LWTFood Sci. Technol. 54(2): 325-330.

Meilgaard MC, Civlle GV, Carr BT. 2007. Sensory Evaluation Techniques. $4^{\text {th }}$ Ed. CRC Press. Boca Raton, FL, USA.

Moller KK, Rattray FP, Bredie WLP, Hoier E, Ardo Y. 2013. Physicochemical and sensory characterization of Cheddar cheese with variable $\mathrm{NaCl}$ levels and equal moisture content. J. Dairy Sci. 96(4): 1953-1971. 
Murtaza MA, Rehman SU, Anjum FM, Haq N. 2008. Nutritional comparison of cow and buffalo milk cheddar cheese. Pak J Nutr. 7: 509-512.

O’Mahony JA, Sheehan EM, Delahunty CM, McSweeney PL. 2005. Lipolysis and sensory characteristics of Cheddar cheeses ripened using different temperature-time treatments. Le Lait. 86(1): 59-72.

Onga L, Henrikssonb A, Shaha NP. 2007. Chemical analysis and sensory evaluation of Cheddar cheese produced with Lactobacillus acidophilus, Lactobacillus casei, Lactobacillus paracasei or Bifidobacterium sp. Int. Dairy J. 17: 937-945.

Pastorino AJ, Hansen CL, McMahon DJ. 2003. Effect of pH on the chemical composition and structure-function relationships of Cheddar cheese. J. Dairy Sci. 86(9): 27512760.

Prinsloo A. 2007. The relationship between consumer acceptability and descriptive sensory attributes of Cheddar cheese, with special reference to free choice profiling. Diss. University of the Free State Bloemfontein, South Africa.

Radlowski M. 2005. Proteolytic enzymes from generative organs of flowering plants (Angiospermae). J. Appl. Genet. 46(3): 247-257.

Sharif M, Farooq U, Malik W. 2014. Citrus marketing in Punjab: Constraints and Potential for Improvement. The Pakistan Development Review (renewed for Economic Survey) 201314. 44(4): 673-694.
Singh TK, Drake MA, Cadwallader KR. 2003. Flavor of Cheddar cheese: a chemical and sensory perspective. Comprehensive Reviews in Food Science and Food Safety. 2(4): 166-189.

Silvestre M, Carreira R, Silva M, Corgosinho F, Monteiro M, Morais H. 2012. Effect of $\mathrm{pH}$ and temperature on the activity of enzymatic extracts from pineapple peel. Food Bioprocess Tech. 5(5): 1824-1831.

Steel RGD, Torrie JH, Dickey DA. 1997. Principles and procedures of statistics. A biometrical approach. $3^{\text {rd }}$ Ed. McGraw Hill Book Co. New York.

Walstra P, Wouters Jan TM, Geurts TJ. 2006. Dairy Science and Technology. $2^{\text {nd }}$ Ed. CRC Press, Boca Raton, FL, USA. pp. 744-773.

Wang F, Zhang XY, Stephanie C, Zhang LD. 2011. FTIR analysis of protein secondary structure in Cheddar cheese during ripening. Spectroscopy and Spectral Analysis. 31(7): 17861789.

Young ND, Drake M, Lopetcharat K, McDaniel MR. 2004. Preference mapping of Cheddar cheese with varying maturity levels. J. Dairy Sci. 87(1): 11-19.

Zheng YR, Liu ZM, Xiao Y, Mo BH, Sun KJ. 2011. Effects of compositional factors on the texture of Cheddar cheese during ripening. Acta. Agric. Bor. Sin.S2. 